\title{
沖縄における多民族関係の形成過程
} 琉球華僑総会龍獅團を事例に

\section{The Process of Emerging Multiethnic Relations in Okinawa}

A Case of the Chinese Dragon and Lion Dance Team of the Overseas Chinese Association in Ryukyu Islands

\section{八尾祥平}

\section{Shohei YAO}

In this paper, I examine how different ethnic peoples can be as one group. For that purpose, I take a case of the Chinese Dragon and Lion Dance Team in Overseas Chinese Association in Ryukyu Islands and show what social classes the team members belong to through researching the Life Histories of the team members.

There are big economical gaps among people living in Okinawa, and Taiwanese have also been divided economically as they lived from generation to generation. It makes Taiwanese difficult to get along with each other in one team even though they belong to the same ethnic group. On the contrary, the members of the new Chinese Dragon and Lion Dance team belongs nearly same social class and also have same attitude to life. This is the bases of their multi-ethnic partnership. The research results show it is possible we have common sense across different ethnic background and that the common sense is different from each member's ethnic back ground. It comes from the new social context made in among the team members.

The most important finding in this case is that the team members can make their own social relations by themselves through being the team member even though they live in highly specialized and individualized urban society.

\section{1. 研究の目的と背景}

本稿の目的は，現代の日本社会における多民族関係の形成過程とその意義を検証するこ とにある。このため, 本稿では多民族関係を考察するための事例として, 沖縄にある台湾 人の同郷会である琉球華僑総会の龍獅團を取り上げる。詳細については後述するが, 琉球 華僑総会の龍獅團のメンバー構成は, 龍獅團の結成当初は台湾人のみだったものの, 現在 では日本人・台湾人・中国人・アメリカ人と多様化している。世界各地に存在する龍獅團 のメンバー構成は, 一般的には華僑・華人で占められており, 琉球華僑総会の龍獅團のよ うに他の民族が参加する（あるいは，参加できる）ことは非常に稀なケースであると考え られる。このような龍獅團は, 現在の日本で盛んに議論がされるようになった「多文化共 
生」の具体的な事例として検討に十分値するだろう。

1980年代後半から日本に打ける外国人登録者数は増加の傾向にある。こうした社会の 変化に対応しょうとする動きは，行政では，ローカルレベルからあらわれるようになっ た。1990年代後半から，「多文化共生」を揭げる地方自治体が登場しはじめ，2001年に は川崎市や浜松市の呼びかけにより「外国人集住都市会議」の発足にこぎつけた［山脇， 2005: 35]。やがて，ナショナルレベルに抒いても，体系的な外国人施策は現在に抒いて も欠如しているものの, 総務省 [2006] から「多文化共生推進プログラム」が提言され るようになった。

日本に打けるエスニシテイ研究の分野では, 厚い研究の蓄積のある都市社会学と国際社 会学との間で活発に議論が交わされている。

都市社会学では，1990年代初頭から都市のインナーシティに暮らすニューカマーによ るエスニック世界生成過程をホスト社会の受容・変容と併せて分析し, 日本人住民と外 国人住民との間に生まれる「共生の作法」を描き出した奥田道大らの研究 [奥田・田嶋, 1991; 広田，2003など］があらわれ，また，ニューカマーの地域社会への流入と日本人 住民側との関係を分析した研究 [都築，1995; 小内・酒井，2001など］や，オールドカ マーである在日コリアンと日本人との民族関係に焦点をあてた研究 [谷編，2002; 二階堂， 2007 などといった厚い蓄積ができつつある。

一方, 国際社会学からは都市社会学に対して, これらの研究に共通してみられる「共 生」概念には，国家や市場といった社会におけるマクロな制度の視点が抜け落ちており， 地域社会において同化主義的な日本人と外国人との関係が示されるにとどまっていると指 摘されている [梶田・丹野・樋口，2005］。

こうした指摘に対して，都市社会学からは，国家や市場といった制度には決してからめ とることのできない，個人の日常的な実践をトランスナショナリズム論の視点から再構成 する方向性 [広田, 2008］や民族関係の生活構造の分析を通して，民族関係の結合から 政治的な「統合」を実現するための過程分析を行うという方向性 [稲月，2008］なぞが 示された。

ところで, 沖縄の地域社会に捛ける外国人を取り扱った研究としては, フィリピン人の オールドカマーとニューカマーとの関係に着目した鈴木・玉城 [1996,1997］や，アメリ 力人・台湾人・日系ペルー人・日系ブラジル人の国際移動の類型化とネットワークについ て分析した野入 [2004，2005］による研究などが挙げられる。これらは沖縄で生活する 個別のエスニック・マイノリティを捉えた優れたモノグラフである。

ただし，先行研究では，マジョリティとしての日本人と個別のエスニック・マイノリテ イの 2 者関係の分析に重点がおかれ，日本の都市社会における多民族関係について考察し た研究はそれほど多くない。管見の限りでは，八尾市に打けるマルチエスニック・コミュ ニティの分析を通して，日本人・オールドカマー・ニューカマーによる多民族関係につい 
て焦点を当てた研究 [高智, 2008］があらわれはじめてはいるものの，今後のさらなる 研究の蓄積が望まれる。

本稿では，エスニシティの異なる現在の龍獅團の團員たちが多民族間結合によって社会 的な集団を形成するにいたった過程を, 各團員の学歴や職歴といった社会的属性の共通性 に着目して分析を行う。このため, 本稿では, 琉球華僑総会の龍獅團の團員の社会的属性 を分析する際には性別・年齢・最終学歴・本人の職業・父親の職業・居住地・使用可能言 語・日本での滞在時期について検討を行う。

本稿では以下の構成により議論を進める。まず, 調査地である沖縄社会の構造を経済社 会的な側面を中心に概観し, さらに沖縄社会における外国人として琉球華僑総会龍獅團の メンバーとなっている台湾人・中国人・アメリカ人の概況をとりあげる ${ }^{1)}$ 。次に, 琉球華 僑総会龍獅團の概要を紹介し，その上でメンバーの多民族化が進んでいった過程と團員の 社会的属性についての分析を行う。そして，多民族間結合の抱える限界について指摘する。 さらに, 琉球華僑総会が龍獅團の多民族化を受容した過程を分析し, 最後に沖縄の都市社 会における龍獅團の活動の意義について考察する。分析にあたつては，筆者が2008年 4 月から 2009 年 11 月初旬にかけて行った龍獅團への参与観察およびメンバー等への聞き取 り調査で得られた知見をもとにすすめていく。ただし, 参与観察に際して, 筆者は龍獅團 の活動に台湾人として参加した。なお, 龍獅團の参加メンバーの経歴や聞き取り調査の内 容については，個人の特定を防ぐため議論の客観性を損なわない程度に改変を行っている。

\section{2. 調査地概況}

\section{2-1 人口}

沖縄県の総人口は，2007年 10 月 1 日現在で $1,373,754$ 人，世帯数は 508,064 世帯で ある。人口密度は 604 人 $/ \mathrm{k} \mathrm{m}^{2}$ 。人口の推移を 10 年毎にみると, 1987 年は $1,204,557$ 人, 1997 年は $1,290,373$ 人となっている。外国人登録者数については, 2007 年末現在で 8,914 人となっており，国籍別の上位 3 力国は米国 $(2,214$ 人) ・中国 $(2,056$ 人)・フィリ ピン（1,685人）となっており，外国人登録者の約 7 割を占めている。なお，米国人につ いてはこれとは別に，2007年 9 月末現在で米軍・軍属とその家族が48,490人滞在してい る。彼らを含めて沖縄に居住する外国人の割合を算出すると $4.0 \%$ となり, 比率としては 東京都 (3.0\%) よりも高くなっている。

\section{2-2 経済状況}

住民の所得状況の推移について，ひとり当たりの県民所得は，1995年度には2149千円， 2000 年度では2,077千円，2005年度では2,021 千円となっており，全国で最も低い水準 にあるだけでなく減少傾向にある。また，ジニ係数は，2004年度についてみると全世帯 
では $0.344 て ゙$ 全国 2 位，勤労世帯では 0.311 で全国 1 位となっている。なお，勤労世帯で ジニ係数が 0.3 を超えるのは全国で沖縄県のみであり, 経済社会的にみて非常に大きな経 済格差が存在している社会であると言わざるをえない2)。

また，完全失業率について，2007年は全国平均が 3.9\%であるのに対して，沖縄県で は $7.4 \%$ となっている。さらに, 生活保護率の推移は, 2001 年度には $1.28 \%(17,109$ 人), 2006 年度では $1.51 \%(20,790$ 人) と上昇傾向にあり, 生活基盤の弱さが数字にも反映さ れていると考光られる。

\section{3. 沖縄社会における台湾人・中国人・アメリカ人の概況}

\section{3-1 台湾人}

台湾人は，現在，統計上では中国人として扱われていること，さらに，沖縄の日本復帰 後に帰化申請して日本国籍を取得し, 統計上は日本人として扱わ机る者も多いこともあり, 正確な人口は把握できない。しかし，復㷌直前には2,000名を超えており，沖縄に居住す る外国人としてはアメリカ人に次ぐ規模に達していた。現在は 4 世や 5 世が産まれている 世帯もあり，家族に台湾人がいる世帯人口は 1 万人弱ほどではないかと言われている ${ }^{3)}$

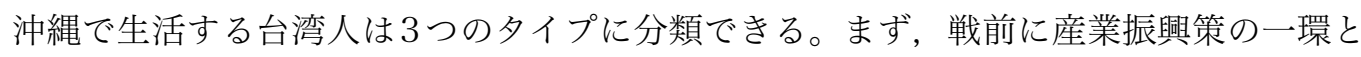
してパインの殖産技術を導入するために台湾から石垣島へ「日本人」としてやってきて， 戦後も台湾には帰らずにそのまま残った人びとである ${ }^{4)} 。$ 次に，1950年代から貿易業を 営む人びとが移住し，彼らは沖縄復興のための物資調達を陰で支える役割を担った。最後 に，1960年代後半から当時の中華民国政府（以下，国府と記す）が沖縄との関係強化を 図る施策の一環として推進した技術者や労衔者の派遣事業によって来沖した人びとである。 1972年に起こった日本と国府の国交断絶により派遣事業が停止となった後，台湾から沖 縄へ新たに移住する者はあまりみられない。

\section{3-2 中国人}

沖縄の中国人は都市部である那霸市および浦添市に集中的に居住している。沖縄へやっ てくる中国人は年々増加する傾向にあり，台湾人とは対照的である。

香港出身者を除くと, 中国人の大半は改革・解放以後に来日した一世にあたる者たちで 占められており，沖縄社会に打けるニューカマーとなっている。中国人の多くは就学・留 学によって来日し, 専門学校や大学卒業後は沖縄の地元企業に就職する者が多い。中国人 への聞き取り調查を行った限りでは，彼らは中国社会において高い階層の出身者であるこ とが多い。大部分が帰化をしたオールドカマーの台湾人とは異なり，あくまでも外国人で あるため行政組織や県内の基幹産業で勤務する者はまだそれほど多くはあらわれていない ものの, 彼らの多くは沖縄社会に抒いて大卒のホワイトカラー世帯としてのライフコース 
を歩んでいる。中国人の同郷組織である沖縄華僑華人総会は2002年に結成されている。

\section{3-3 アメリカ人}

米軍基地の存在を背景にして沖縄におけるアメリカ人は沖縄社会における最大のエスニ ック・マイノリティ集団となっている。米軍人・軍属およびその家族は, 他の外国人とは 異なり，日米地位協定によって日本における身分が保障されている。

米軍人・軍属とその家族の大半は基地内に居住しているが，基地外の賃貸住宅に居住す るひとびともいる。彼らはたいていの場合, 3-5年ほどで他の地域へと転勤となり, 沖縄 から離れる。ただし，除隊後も沖縄で仕事を見つけ，外国人登録を行い沖縄社会に定住す る者も存在する。沖縄に定住するアメリカ人の大半はこうした人びとである。また，アメ リカ人と日本人との間に生まれたアメラジアンもおり, 彼らにあった教育を行うための機 関であるアメラジアン・スクールが存在することも沖縄社会の特色のひとつである。さら に，アメリカ人は基地周辺部にあたる中部地域に多く居住し，地元の文化に興味を持ち， 実際に地域にあるエイサーなどの団体へ参加する者も少なくない。

\section{4. 龍獅團の多民族化進行過程}

\section{4-1 琉球華僑総会および龍獅團の概要}

琉球華僑総会は 1971 年 3 月に設立された。当時, 沖縄では翌年に日本復帰をひかえ沸を き立つ沖縄県民とは対照的に台湾人の間には復帰後の自らの地位の保障がどのようになさ れるのかについて不安が広がっていた。こうした個人では解決し得ない問題を話し合い, 解決を目指すための場を求める動きが琉球華僑総会の設立に結びついていった。2009年 現在, 琉球華僑総会は約 200 名の会員がおり 5), 会則に則り, 会員の中から選挙によって 会長 1 名, 理事 8 名, そして監事 1 名が選出され, 彼らが会の運営を担っている（任期は 3 年間)。琉球華僑総会は沖縄で暮らす台湾人の親睦を深める活動だけでなく, 近年は沖 縄社会との交流を深めるために県内で行われる様々な国際交流イベントにも招聘されるよ うになり，地域社会の中での認知度は次第に高まってきている。

琉球華僑総会の内部組織として青年部が2002年に設置された（現在は活動休止状態）。 青年部が設置された目的は次世代育成と次世代の若い華僑同士の親睦を深めるためであっ た。青年部は若い世代の会員だけで活動を任せるのではなく，理事のひとりである T1さ んが担当理事として彼らの後見役・相談役とする体制をとることとなった。

青年部の発足とほぼ同時に, 台湾政府から琉球華僑総会へ中華の伝統文化である龍舞お よび獅子舞用の龍と獅子がそれぞれ贈呈された。これをうけて, 青年部の活動として龍 舞・獅子舞を行うために龍獅團が結成された。

一般的に, 中華の龍舞・獅子舞は祝い事の際に行われる。たとえば，建国記念のお祝い 
や新年のお祝いだけにとどまらず，結婚や家の新築祝い等の場合にも行われることがある。 琉球華僑総会龍獅團による演舞は，演舞の依頼を受けた後で理監事会においてその可否を 諮る。演舞の可否は，開店祝いのような私的な祝い事ではなく公共性の高い行事であるか 否かによって判断される。現在では中華民国の建国記念や旧正月のパーティといった琉球 華僑総会の催しだけでなく, 沖縄の地域社会における最大級のお祭りである那覇祭り [写 真参照] や首里城祭, さらには米軍基地内での子供たちが異文化を学ぶためのイベント等, 華僑以外の沖縄の地域住民たちとの交流を深めることが可能な行事への参加を依頼されて 演舞を行う機会も増え, 沖縄社会における龍獅團の認知度は高まっており, このことが結 果として琉球華僑総会の認知度も高めることにつながっている。

また，台湾政府は世代を超えて華僑が華僑としてのアイデンティティを維持することを 積極的に支援している。龍や獅子の贈呈もその一環であり, 毎年, 台湾政府は海外の華僑 団体から要請をうけ，龍舞・獅子舞の講師を海外へ派遣して講習を行っており，琉球華僑 総会でも過去に講師の派遣を受けたことがある。このように, 必ずしも全ての華僑が龍 舞・獅子舞に精通しているわけでは当然ないにしても, 龍獅團は世界中に存在している。 さらに，世界各国から選抜された龍獅團による演舞の世界大会が毎年開かれており，こう した活動は世界中の華僑のネットワークを強化する機会にもなっている。このように龍獅 團は華僑のネットワークを維持・強化するための役割も持っているため, 龍獅團の團員に 華僑以外の者が加わることはこれまで稀であった。ホスト社会の人間が中心となっている のは，管見のかぎりでは神戸の市立高校の事例があるのみである [岩井，2005]。

琉球華僑総会の龍獅團については, 結成当初の團員数は約 20 名で, 全員が台湾人であ った。團長には青年部の担当理事であった T1さんが就任した。龍獅團自体には設立当初 から現在にいたるまで團の規約というものは存在していない。2008年現在, 琉球華僑総 会の青年部は活動休止状態であり, 龍獅團結成当初の台湾人メンバーは團長である $\mathrm{T} 1$ さ ん以外は誰ひとりとして参加していない。つまり, 現在の琉球華僑総会の龍獅團の活動は, 実質的には青年部とは別組織の活動として継続されている。

現在, 龍獅團の團員は 12 名おり, 国・地域別の内訳は台湾人 2 名, 中国人 5 名, 日本 人 2 名, アメリカ人 3 名となっている。上記の通り, 一般的に龍獅團の團員は華僑がなる もので，華僑以外の人間が加わることは稀である。琉球華僑総会の龍獅團ではホスト社会 の人間のみならず，他の外国人が團員として加わっており，おそらく世界でも類例のない 事例である。

龍獅團の具体的な活動としては, 週 1 回の練習のほかに年 10 回ほど依頼を受けて演舞 を行っている。アメリカ人が中部地域に居住している以外は, 他の團員は那覇市近辺に居 住しているため，練習は那覇市近辺の公民館を利用していたが，地域の住民と公民館の利 用をめぐり行き違いからトラブルが起こり公民館の利用が難しくなったため, 2008年か ら現在にいたるまで中国からの留学生が加入したことをきっかけに彼らの学校の施設を利 
用させてもらうようになった。また，進学 や転勤といったやむを得ない事情で沖縄を 離れる團員もおり, 團員の入れ替わりが激 しく, 恒常的に演舞を行うのに十分な團員 を確保することは, 練習場所の確保と並ぶ 龍獅團の最大の課題のひとつとなっている。

\section{4-2 台湾人間の分離}

本節では, 琉球華僑総会龍獅團の設立当 初の團員が，同じ民族であるにも関わらず

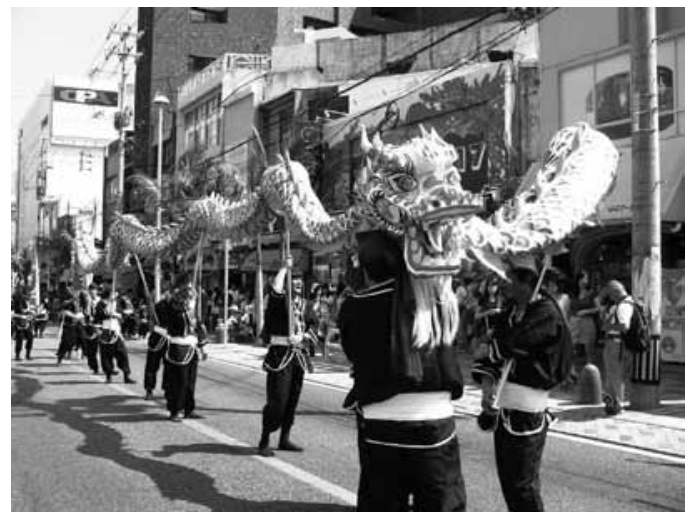

写真 那覇祭りでの演舞 分離関係が生じてしまった過程を台湾人團 員への聞き取り調査から得られた彼らの社会的属性を踏まえて分析していく。なお，設立 当初の團員全員に聞き取り調査に応じてもらえた訳ではなく，團長である T1 さんとかつ ての團員であるはT2さんと T3さんのわずか 3 名から聞き取りが行えたに過ぎない。ただ し，T2さん・T3さんは青年部と龍獅團がほぼ連動していた時期に若手のリーダーとして の役割を担い, 後に $\mathrm{T} 1$ さんとの確執から青年部が活動休止を決定した際にも中心的な役 割を果たした人物である。このため，台湾人間で分離関係が生じてしまった原因を全て解 明できたわけではもちろんないが，主要因についてある程度は明らかにできたと考光る。

以下の表 1 によめられた 1 ・ T2・T3さんの経歴と聞き取りの結果から， T1 さんと T2・T3さんとの間には以下に述べるような大まかな社会的属性に違いがあらわれている と考光られた。T1さんは父親が苦労をして沖縄社会に根付こうと苦労していた時期を知 っており，高校卒業後は自らも父親と同じょうに個人事業主として生計をたてているのに 対して，T2・T3さんは父親が沖縄社会で一定のポジションを得た後の姿をみて育ち，自 らは大学を卒業し, 企業の経営者や管理職として人材を効率的に配分する業務に携わって いる。つまり，T2・T3さんはT1さんと比較して高学歴，かつ，より高度で専門的な組 織管理法を身につけている者として位置づけられる。

琉球華僑総会に青年部が設置され，理監事から青年部の活動に参加するように声をかけ

表 1 設立当初の團員の経歴

\begin{tabular}{|c|c|c|c|c|c|c|c|c|c|}
\hline & 出生地 & 年齢 & 性別 & 最終学歴 & 本人の職業 & 父親の職業 & 使用可能言語 & $\begin{array}{l}\text { 来沖のきっ } \\
\text { かけ }\end{array}$ & $\begin{array}{l}\text { 沖縄での滞 } \\
\text { 在時期 }\end{array}$ \\
\hline $\mathrm{Tl}$ & 台湾 & 53 & 男 & 高校 & 自営業 & 自営業 & $\begin{array}{l}\text { 日本語·北京語· } \\
\text { 英語 }\end{array}$ & 親の移住 & $\begin{array}{l}1969 \text { 年〜 } \\
\text { 現在 }\end{array}$ \\
\hline T2 & 日本 & 41 & 男 & 大学 & 中小企業経営者 & 中小企業経営者 & 日本語 & - & $\begin{array}{l}\text { 出生してか } \\
\text { ら現在まで }\end{array}$ \\
\hline T3 & 日本 & 41 & 男 & 大学 & 上場企業社員 & 会社員 & 日本語 - 北京語 $\mid$ & - & $\begin{array}{l}\text { 出生してか } \\
\text { ら現在まで }\end{array}$ \\
\hline
\end{tabular}


られた際に $\mathrm{T} 2$ ・T3さんは自分達が華僑として会の発展のためにどのような貢献ができる のかを考えた際に，自らが職務を通して得た経験を活かして会の運営を効率化させること が自然に思い浮かんだという。これは彼らにとってはごく「自然」な考えではあったもの の，この考えが，龍獅團の運営を巡ってT1さんとの間に軋轢を生じさせるもとになった。 T3さんはT1さんとの摩擦の原因を,「世代による物事の進め方の違い」にあると認識し ている。T3さんは, 裸一貫で沖縄へ渡り吒き上げてきた者の多い 1 世・2世を尊敬して はいるものの, T3さんをはじめとする 3 世の多くは沖縄社会のなかで比較的大きな組織 の運営を担っている者が多いため, 物事の考え方が異なってきていると考えている。龍獅 團の運営にあたっても，T3さんは，上の世代のように顔見知り同士が阿吽の呼吸でバラ バラに活動を行いながらも帳尻を合わせていくのではなく，規模は小さくとも組織として 規律をもって運営すべきであると考えていた。このように，自らの才覚だけを頼りに個人 事業主として事業に取り組んできた $\mathrm{T} 1$ さんと, 親の世代から社会上昇を遂げ, 比較的規 模の大きな企業で経営者や管理職としての職務経験を有し, 比較的高度で効率的な組織管 理の方法を身につけている $\mathrm{T} 2$ ・T3さんとの間では, たとえ同じ民族の者同士であったと しても，龍獅團の運営において意見の一致を見ることが難しかったのである。

T3さんはこうした社会的属性の差を「世代間の差」と認識しているものの，T1さんへ の聞き取り調査からこうした差が必ずしも「世代間の差」とは一致しないことが示唆され た。T1 さんは, 青年部が設立された当初, 若い華僑が親睦のために飲み会に集まるだけ でなく，何か共通の活動を通しても集まるきっかけをつくる必要があると感じていた。そ の理由は「沖縄の給料は安い」ために, 全ての若い華僑が飲み会へ毎回参加できるわけで はなく，また，そのことを自らが言い出しづらいがために徐々に青年部の集まりから足が 遠のいていく者がひとり，また，ひとりとあらわれていることに気づいていたからである。 つまり，T1 さんにとって，設立当初の龍獅團の活動は，若い華僑たちが集まりやすくす る意味合いもあったのである。これはあくまでも T1 さんの主観に基づく発言に過ぎない が，若い世代同士であっても，龍獅團のメンバーは必ずしも T2さんや 23 さんのような相 対的にみて高い社会的地位に就いているわけではなく，沖縄のような階層間格差の大きな 地域社会では若い世代にもこうした格差が目に見えない形で龍獅團の團員間の結束に影響 を及ぼしていることが推察された。沖縄の都市社会における台湾人と階層分化の影響につ いては今後の更なる検討の課題としたい。

こうして華僑としてのアイデンティティの継承や結束の強化を目指して結成された龍獅 團は，團員間に横たわる社会的属性の違いを克服できず徐々に参加者が減っていき，その 穴を埋めるために当初は「仕方なく」台湾人以外の人間を呼び込まねばならなくなった。 こうして龍獅團は多民族間結合を媒介する組織へと徐々に変容していくこととなった。 


\section{5. 多民族間の結合と社会的属性}

\section{1 加入のきっかけ}

現在の龍獅團の加入のきっかけについては, 以下の表 2 の通り，勧誘あるいは飛び入り の $2 つ に$ 分類される。團長を除いた 12 名の團員のうち, 他の團員からの勧誘により加入 した團員は10名であるのに対し，たまたま演舞をみて飛び入りで加入を申し出た加入者 は2名であり，圧倒的に勧誘が多い。勧誘は，友人・知人の関係から行われるケースが主 流となっている。

友人関係から外れる勧誘のケースとして，アメリカ人の家族である A 1 ・A2・A3さん のケースについて取りあげる。Alさんの一家はもともと沖縄県中部にあるエイサーサー クルに所属していた。中部で行われたエイサー祭りの際に彼らが演舞をしているのを見つ けた J1 さんが「沖縄のことに興味があるなら，中国のことにも興味を示すかもしれない」 と考え勧誘したことが入團のきっかけとなっている。

特筆すべきは，中国人である C1 さんと C2 さんのケースである。上に述べたように台 湾側の華僑総会では龍舞・獅子舞の知識や技術をもっているものの演舞を行うために十分 なだけの團員を確保できずにいた。これに対して, 中国側の華僑華人総会では, 中国政府 から龍舞用の龍が贈呈されたものの, 龍に魂を吹き込む儀式や演舞の方法については知識 がなく，演舞を行う人間を確保できても活動できない状態であった。沖縄華僑華人総会の 当時の会長がこの件について, 個人的に T1 さんへ相談したところ, 中国人が琉球華僑総 会の龍獅團に参加すれば龍舞について学ぶ機会になると勧誘し, 沖縄華僑華人総会の会長

表 2 現在の團員の経歴

\begin{tabular}{|c|c|c|c|c|c|c|c|c|c|}
\hline & 出生地 & 年齢 & 性別 & 学歴 & 本人の職業 & 父親の職業 & 使用可能言語 & \begin{tabular}{|l|} 
来沖のきっ \\
かけ
\end{tabular} & \begin{tabular}{|l} 
沖縄での滞 \\
在時期
\end{tabular} \\
\hline $\mathrm{T} 1$ & 台湾 & 53 & 男 & 高校 & 自営業 & 自営業 & $\begin{array}{l}\text { 日本語·北京語· } \\
\text { 英語 }\end{array}$ & 親の移住 & 1969 年〜現在 \\
\hline $\mathrm{T} 4$ & 日本 & 30 & 男 & 大学 & 上場企業社員 & 上場企業社員 & 日本語 - 英語 & 転勤 & 2008 年〜現在 \\
\hline $\mathrm{Jl}$ & 日本 & 30 & 男 & 高校 & 自営業 & 自営業 & 日本語 & - & - \\
\hline $\mathrm{J} 2$ & 日本 & 30 & 男 & 高校 & 機械工 & 電気工 & 日本語 & - & - \\
\hline $\mathrm{Cl}$ & 中国 & 29 & 男 & 大学 & 中小企業経営者 & 農業 & 日本語・北京語 & 進学 & 2000 年〜現在 \\
\hline $\mathrm{C} 2$ & 中国 & 27 & 男 & 大学 & 上場企業社員 & 運輸業 & 日本語 $\cdot$ 北京語 & 進学 & 2000 年～現在 \\
\hline C3 & 中国 & 19 & 男 & 高校 & 学生 & 会社員 & 日本語・北京語 & 進学 & 2008 年～現在 \\
\hline $\mathrm{C} 4$ & 中国 & 19 & 男 & 高校 & 学生 & 中小企業経営者 & 日本語 $\cdot$ 北京語 & 進学 & 2008 年〜現在 \\
\hline $\mathrm{C} 5$ & 中国 & 19 & 男 & 高校 & 学生 & 中小企業経営者 & 日本語 - 北京語 & 進学 & 2008 年〜現在 \\
\hline $\mathrm{Al}$ & 米国 & 44 & 男 & 大学院 & 軍人 & 電気工 & 英語 & 転勤 & \begin{tabular}{|l|}
$1992 \sim 1995$, \\
2003 年 現在 \\
\end{tabular} \\
\hline A2 & 米国 & 40 & 女 & 大学院 & 主婦 & 軍雇用者 & 英語 & 夫の転勤 & \begin{tabular}{|l|}
$1992 \sim 1995$, \\
2003 年 現在
\end{tabular} \\
\hline A3 & 米国 & 20 & 女 & 大学 & 学生 & 軍人 & 英語·日本語 & 父の転勤 & \begin{tabular}{|l}
$1992 \sim 1995$, \\
2003 年 現在
\end{tabular} \\
\hline
\end{tabular}


はこれをうけて，会長の命により C1 さんと C2 さんが龍獅團に参加するようになった。中 国と台湾が政治的に分断されているため, 沖縄においてもお互い対立することはないにせ よ台湾人の会と中国人の会が個別に存在している状況にも関わらず，政治的な問題からは 距離を置いて協力関係が見られる点で，華僑社会のなかでは珍しい事例である。

最後に，飛び入りで加入した台湾人の T4さんと中国人の C3さんについてとりあげる。 T4さんは東京で生まれ育った台湾人で, 日本の企業に就職し, 転勤で沖縄へやってきた。 C3さんは上に述べた通り, 中国からの留学生である。2人とも中華の龍舞・獅子舞の存 在については知ってはいたものの, 自らが参加した経験は全くなく, 沖縄のお祭りで龍獅 團による演舞を見たことがきっかけとなり飛び入りで龍獅團に加入することとなった点で 共通点がみられる。

\section{2 社会的属性の共通性}

現在の團員の社会的属性にどのような共通性が見られるのかを検討する。ただし，中国 人の留学生である C3・C4・C5さんらは中国の高校卒業後, 日本の学校へ進学する準備 のために沖縄へやってきており，1年も経たないうちに全員が東京へ進学してしまったた め, 沖縄の都市社会に比較的長期にわたって居住しているとは言い難い部分があり，本稿 においては分析の対象からは外すことにする。

まず，地元の沖縄社会で生まれ育った J1・J2さん以外の團員の来沖のきっかけについ ては，働く場所との関わりによるパターン $(\mathrm{T} 1 ・ \mathrm{~T} 4 \cdot \mathrm{A} 1$ 一家) と，進学といった学業と の関わりによるパターン $(\mathrm{Cl} \cdot \mathrm{C} 2)$ の 2 つに分類される。特にアメリカ人である Alさん については沖縄に米軍基地が存在すること, 中国人である $\mathrm{Cl} \cdot \mathrm{C} 2$ さんは海外渡航が制限 されており進学や就学でなければビザが発給されないという各国の事情が反映されている。

次に, 職業については, 都市の自営業者層 $(\mathrm{T} 1 \cdot \mathrm{J} 1)$, ブルーカラー層 $(\mathrm{J} 2)$, ホワイ トカラー層 $(\mathrm{T} 4 \cdot \mathrm{Cl} ・ \mathrm{C} 2)$, 軍人 $(\mathrm{Al}$ 一家 $)$ に分類できる。 $\mathrm{Al}$ さんは高度な技術をも ったエンジニアとして職務についており，実態としてはホワイトカラー層に近いと考えら れる。

なお，外国籍をもつ團員には沖縄での定住への強い志向がみられる。C1・C2 さんは沖 縄の大学を卒業後, 自ら事業を興す $(\mathrm{Cl})$, 地元企業に就職する（C2）といった差はあ るものの長期間にわたり沖縄を自らの生活の場とする志向が強い。また, Aldんについ ても他の基地への異動により間が空いているものの，本人の強い希望で沖縄に約 10 年勤 務しており，退役後も軍雇用員等として沖縄に残り定住したいと考えている。彼の娘であ るA3さんは人生の大半をアメリカではなく沖縄で過ごしているため,「わたしはウチナン チュだよ。アメリカ人じゃないさ」と認識している。母親のA2さんによれば，アメリカ 内にいても基地の内部では一般のアメリカ社会とは異なる生活習慣が多くあり, このため, 基地で生まれ育ったアメリカ人は, 一般のアメリカ人から,「アメリカ人とは少し違うひ 
とたち」と見られることがままあるそうである。こうしたこともあり，A3さんも「でき ることなら（慣れ親しんだ）沖縄でずっと生活したい」と希望している。

最終学歴については, 高卒 $(\mathrm{T} 1 \cdot \mathrm{J} 1 \cdot \mathrm{J} 2)$, 大卒以上 $(\mathrm{T} 4 \cdot \mathrm{C} 1 \cdot \mathrm{C} 2 \cdot \mathrm{A} 1$ 一家) とな っている。ただし, A3さんについては現在の最終学歴は高卒ではあるものの大学生であ るため大卒以上とみなして分類した。

龍獅團の團員の学歴と職業を併せてみると, 大卒のホワイトカラー層 $(\mathrm{T} 4 \cdot \mathrm{C} 1 ・ \mathrm{C} 2 \cdot$ $\mathrm{A} 1$ 一家）と高卒の非ホワイトカラー層（T1・Jl・J2）に分化しているょうに見える。し かし, 大卒のホワイトカラー層の團員に個別に行った聞き取り調査から, 彼らの多くは父 親の学歷が高卒以下の非ホワイトカラー層の家庭で生まれ育っていることがわかった。

$\mathrm{Cl}$ さんは中国でもトップレベルの大学を卒業した後に沖縄へ留学し, 卒業後は自らの 手で事業を起ち上げているものの, 彼の実家は中国の内陸部で農業を営んでおり, 「中国 はいまとても発展してきているけ机ど，うちの近くはまだまだこれからで貧しいところも 多いよ」と語っていた。C2さんの父親は運送業に従事しており, C2さんは留学中, 仕送 りは極力もらわずに自力で生活費と学費を稼いでいたという。

また, $\mathrm{A} 1$ さんと $\mathrm{A} 2$ さんについては, $\mathrm{A} 1$ さんの父親はブルーカラーであり, $\mathrm{A} 2$ さんの 父親は軍雇用員として慎ましい生活を送っていた。高校卒業後, Al さんは建設現場での 仕事に従事しており, 一方の A2さんは高校卒業後に歯科助手などをして働いていた。結 婚を機に $\mathrm{Al}$ さんは家族を養うために軍隊へ入隊し, 軍人とその家族は基地内の大学にお いて無償で学べることを利用して大学院まで卒業し, 退役後の生活のために幾つかの資格 も取得している。Aldん一家にとって軍隊への入隊は社会上昇のきっかけとなっているが, 以前と比べ生活に余裕のある現在においても自らが生まれ育った慎ましくある生活を尊ぶ 姿勢を保ち続けている。

T4さんについては父親も大卒のホワイトカラー層であるのだが，父親の兄弟たちは高 卒で, 東京の商店街で自営業を営しでいる。T4さんは商店街に隣接した地域で生活して おり, 幼い頃から商人の家庭がぞういったものであり, 商店街の中で人びとが助け合って 暮らしているのを見て育った。自らが商家の出身であることを強く意識するょうになった のは大学卒業後に就職してから, 自分と同じょうな学歷・職歷をもつ同期のなかに「大卒 なのに物を売る仕事をするなんて恥ずかしい」と愚痴をこぼす者に少なからず出会い，物 を売ることを恥ずかしいことと感じる価值観があることに驚かされてからだという。

以上から, 龍獅團の團員には表面的には社会的属性には分化がみられるものの, 本人あ るいは家族の社会上昇の過程も併せてみれば，各自の出身地は異なるものの彼らがもとも と属していたと考元ら机る社会的属性は都市で暮らす非大卒の非ホワイトカラー層（自営 業層・ブルーカラー層) であるという共通性があると考元られる。

\section{3 團員間の関係性}


現在の龍獅團は，台湾人・中国人・日本人が多いこともあり，原則としては年歯階梯制 をとり，團長であるT1さんを頂点にして活動を行っている。ただし，アメリカ人にとっ て年齢階梯制はあまりなじみのないものであることを考慮し，それほど強い強制力はない。

T1 さんは他の團員から, 海外から沖縄へやってきて自らの才覚のみで成功した人物と して尊敬をうけている。特に，かつての $\mathrm{T} 1$ さん同様に海外から沖縄社会へ根付こうと努 力している $\mathrm{Cl} \cdot \mathrm{C} 2$ さんたちのロール・モデルとして様々な相談もうけている。皮肉なこ とに, 中国人の C1さん・C2さんの方が台湾人の若い世代よりも T1 さんとの間に親密な 関係を築きあげている。

團長である T1 さんの下には龍の頭として C2さん, 獅子の頭として 1 さんがおり, 彼 らが演舞のリーダーとなっている。彼らが頭として選ばれたのは，年齢や出身には関係な く, 純粋に演舞における実力が最も高いと他の團員から認められたためである。これに対 して, C2さんも J1さんも「中国人である」,「日本人である」ということよりも「龍獅團 の團員である」ことを優先して活動に取り組む姿勢をとり頭としての責任を果たそうとし ている。たとえば, C2さんは中国人の華僑総会のイベントよりも龍獅團の演舞を優先し, 仕事のスケジュールも極力演舞にあわせ，自らが必ず参加できるように努力している。こ れはT1さんの「顔を立てる」ことにもつながる。一方の $\mathrm{J} 1$ さんは現在, 台湾から派遣さ れた講師による指導をうけた唯一の團員であるため, 自らの文化の直接のルーツではない ものの獅子舞の演舞を指導し続けることが自らの責任であると考えている。こうした姿勢 は團員たちから彼らに対して更なる敬意がはらわれるという循環を生み出している。

龍獅團の團員の最大の共通言語は日本語となっており，適宜，英語や北京語によっても コミュニケーションがとられている。多少の不便はあったとしても，全員が特定の言語を 話すことを強要するような息苦しい関係性はみられない。ほぼ全ての團員からは「何人と かってことは関係ないよ」という発言が聞かれ, 各團員のエスニシティは異なっていても, 龍獅團の團員として演舞に取り組む経験を積み重ねていくにしたがって，お互いの話せる 言語には多少の違いがあるにせよ, 團員がお互いに信頼し合い, 敬意をはらう関係が徐々 に醸成されてきたあらわれのひとつと考えられる。

\section{4 多民族間結合の限界}

現在の龍獅團の團員間には，エスニシテイの差を超えて，社会的属性に共通点が見られ ると考えられる。その結果，メンバーの間にはこうした結びつきから相互扶助の精神に基 づいた関係を生みだし得るのかについて考えるため，以下の事例を取りあげたい。

あるメンバー（本人を特定しないため以下，Xさんと記す）がこれまでの職務経験を活 かし，自らのアイデアをビジネスで試すことを目的に独立をはかった。その際に，事業を 開始するにあたっては何かと資金が必要となろうということで，他のメンバーは，Xさん には何も言わず, T1さんにXさんを助けるために少額ではあるものの模合を興すことを 
内々に相談したことがあった。

模合とは，沖縄ではいまもよくみられる相互扶助システムによる頼母子講の一種である。 鈴木 [1986] によれば，模合は大まかに「金融模合」と「親睦模合」に分類できるとい う。「金融模合」は事業資金を融通するために事業主同士で集まり，扱う金額の規模が比較 的大きいのに対して，「親睦模合」は友人同士が集まり親睦を深めるために行われるので 金額自体はそれほど大きくない。ただし，両者の間には明確な区別があるわけではないと されている。たとえば，結婚する友人のために模合を興し，結婚資金の一部を助けるよう な場合がこうした事例にあたる。Xさんのために提案された模合も金額としては親睦模合 の範囲内に拉さまるもで，事業資金を十分にまかなえるような規模ではないものの，友 人として助けられる範囲では協力したいという團員の思いからなされており，「金融模合」 と「親睦模合」の区別をつけづらい事例に分類できる。

T1 さんは團員から提案された模合を興すことについては反対をした。その理由として， T1 さんはふたつ挙げた。ひとつは, 長引く不況で給料が減らされており, 少額でも模合 を興す余裕はそれほどなく，他のメンバーが出すのにたまたまやりくりが間に合わず自分 は出せなくなってしまった場合，龍獅團へ参加しづらくなる者があらわれる可能性がある こと。もうひとつは, 万一, Xさんが資金を返せなかった場合, 他のメンバーは友人だか らそれを気にしなかったとしても，Xさんは龍獅團に集まりづらくなると考えられること。 そこで, $\mathrm{T} 1$ さんは他のメンバーの気持ちを波んでXさんが困ったときには彼が個人的に 面倒をみるということでこの話は決着させた。

このT1さんとメンバーのやり取りからは，一般的に沖縄の地域社会は相互扶助の精神 が残っていると言われているものの，長引く不況によって，こうした相互扶助そのものが 困難になってしまっている沖縄社会の深刻な現状が浮き彫りになってはいまいか。多民族 間結合によってできあがった龍獅團は小さな社会ではあるが，小さな社会では個人レベル での経済的な問題を解決する余力すらそしい，厳しい状況にあることを認めざるをえない。

上記の事例は，エスニシティの異なる多民族間結合による社会集団からも相互扶助関係 を生み出すことは十分に可能であることを示唆しているものの, 社会構造上の問題の解決 については必ずしも有効な手段とはなりえないという点ではその限界も示されている。

\section{5 琉球華僑総会における龍獅團の多民族化の受容について}

琉球華僑総会において，龍獅團の多民族化はごく「自然」なものとして受容されたわけ ではなかった。まず，龍獅團の活動はそもそも海外で生活する華僑に自らのアイデンティ ティを継承させるという目的のために現在も台湾政府がその活動を支援している点では非 常に政治的な意味合いも含んだ活動である。こうした政府による政策は, 龍獅團の構成員 が台湾華僑であることを前提としている。また，こうした政府の政策的な意図から離れて も, 琉球華僑総会は, 沖縄で生活する台湾人の同郷会として会員間の親睦を深めていくこ 
とを目的とした会であり，そのために新年会や敬老会などの行事も盛んに行われている。 こうしたなかで龍獅團も台湾人同士の親睦を深めるために，台湾人が担っていくことは当 然のこととして会員には認識されていた。

このため，龍獅團から若い世代が抜け，それを補うために非台湾人が参加するようにな った当初は, 華僑の長老だけでなく, 琉球華僑総会の現役の幹部からも「何故, 台湾人で ない者を龍獅團に参加させているのか」という声が團長である $\mathrm{T} 1$ さんに向けられること がたびたびあったという。しかし，琉球華僑総会の会員の中には「会の活動に貢献してい るのであれば，それが台湾人以外の者であっても構わないのではないか」と非台湾人が龍 獅團へ参加することを擁護する者も少なからず抢り，会の中でも意見が分かれていた。そ こで, 理監事間で協議を重ねた結果, 人手不足という現実も踏まえ, 琉球華僑総会におけ る龍獅團の活動を華僑と沖縄で生活する華僑以外のひとびとを結びつけ交流を深めるため の事業と捉えな掞し，会としても龍獅團の活動に非台湾人が参加することを正式に認めら れるようになった。これ以後, 台湾の建国記念や新年のお祝い以外にも那覇祭りのような 沖縄社会のイベントに龍獅團が参加し, 演舞する機会も増加した。さらに, 従来は台湾人 同士の親睦に重心があった会の活動が全般的に見直された結果，これまでに行われてきた 他の活動や行事についても沖縄の地域社会との交流を進めるための機会として再定位され， 外部の友好団体との交流が深まるという効果がもたらされた。こうした龍獅團の多民族化 をきっかけとした琉球華僑総会の変化については今後の更なる研究の課題としたい。

\section{6. 多民族間結合の媒介としての龍獅團の意義}

本稿では日本における多民族関係を考察するために，多民族間結合を媒介する社会集団 として琉球華僑総会龍獅團の事例を取りあげた。本来は台湾人の組織であった龍獅團に日 本人・中国人・アメリカ人が加入した背景には台湾人側の担い手不足の問題があり，また， 多民族間結合が㧍こった背景には沖縄県の南部から中部にかけての都市部における外国人 人口の多さという地域性が反映されたものと考元られる。また，多民族間の結合関係を可 能にした要因としては龍獅團の團員たちの間に社会的属性の面で共通性がみられたことが 大きい。彼らは，エスニシティは異なるものの，大まかにいえば，都市に打ける自営業層 やブルーカラー層の出身者たちであった。

龍獅團での活動が自分と異なるエスニシティ集団の活動であることや團員間のエスニシ ティの違いが分離関係には結びつかず，團員にはその人の社会的な地位とは関係なく，龍 獅團の活動にいかに貢献したかで信頼や敬意をえられるというシステムが龍獅團の内部に は形成されていることも確認できた。多民族間結合によって生まれた信頼関係を生み出す システムは, 各團員のもつエスニシティの社会的な文脈からはいったん切り離された, 團 員間でのみ共有される独自の価値観を形成している点が大きな特徴となっている。これは 
異なるエスニシティ集団に属する者たちの間である程度共通の価值観が形成される土壤が あることが必要であり，それを担ったのが社会的属性の共通性であったと考えられる。

龍獅團の團員の間には相互扶助関係を生み出しうる可能性はあるものの, 経済社会的な 要因からそれが抑制されている点で限界のあることも明らかとなった。しかし, 現在の龍 獅團の規模では社会構造的な問題に対処するには自ずと限界があるのは当然のことである。 また，こうした限界が龍獅團の存在のもつ意義を失わせることは決してないと考える。

現在の多民族化した龍獅團のもつ意義とは何か。そのひとつとして，一般的に閉鎖的な 社会集団を形成しているとみなされがちな華僑が社会において異なるエスニシティをもつ 人々との交流を拡大するための社会的な回路を開くために自らを見直すきっかけとなった ことが挙げられる。さらに, 龍獅團の活動は, エスニシティは異なるものの社会的属性が ある程度共通する人びとが集まり，マジョリティに同化していくのではなく，マイノリテ イであることを顕現させながらホスト社会において認知される社会集団を形成することは 可能であることを示した点も意義深い。沖縄の都市部においても行政や大企業による社会 関係が増大することで専門化と個人化が高度に進み, それ以外の社会関係の発達が難しく なっていることはよくいわれている。こうした中で, 行政や大企業などで中心的な役割を 担う立場にない人びとが，独自の価值観に基づいた社会関係や生活様式を自らの手でつく りあげることはいかにして可能となるのか。龍獅團における多民族間結合によって生み出 された数々の社会関係は，単純にエスニック・マイノリティの問題としてではなく，まさ にこうした現代社会の中心的な課題に対しても示唆を与える側面がある。そして, 変化の 激しい現在の社会に龍獅團の活動から生み出された新しい社会関係を根付かせることはど のようにして可能であるのかという問いが私たちへ新たにむけられているのである。

付記 本稿は，文部科学省研究費補助金（特別研究員奨励費）による成果の一部である。

\section{注}

1）本稿では，来日の歴史的な背景や社会構造が異なっていることから，便宜的に台湾人と中国人 を異なるカテゴリーに分類して分析を行う。筆者には特段の政治的意図はない。

2） 2007 年度の人員規模が 30 人以上の事業所における労㗢者の賃金水準については, 調査産業全 体では299,015円となっている。これに対して，県内で賃金水準の高い業種の上位 3 位までを挙 げると,「電気・ガス・熱供給・水道業」(594,300円), 「教育学習支援業」(537,547円),「金融・ 保険業」(396,850円）となっており，一人あたり県民所得と比較してその賃金水準の高さは突出 している。さらに, 沖縄には基地地主として就業せずに地代のみで十分な生活を行っている人々 も存在している。

3） 2008 年 5 月，琉球華僑総会の会長への聞き取り調査による。

4）戦前に石垣島へやってきた台湾人については野入 [2008］に詳しい。

5）琉球華僑総会は世帯主のみが会員となることが多いため, 実際には会員とその家族が会の様々 な活動に参加している。 
文献リスト

広田康生，2003，「発想としての『トランスナショナル・コミュニティ』と都市エスニシティ論— 都市コミュニティ研究の新文脈——」新版エスニシティと都市』有信堂，299-324.

——, 2008,「都市社会学はなぜエスニシティ研究をテーマ化したか—ーランスナショナリ ズム論からの新たな展開——」都市社会学会年報』26:57-72

樋口直人, 2005,「エスニシティの社会学」, 梶田孝道編『新・国際社会学』名古屋大学出版会, 24-41.

法務省，2008，『在留外国人統計 平成20年版』.

稲月正，1997，「地域社会と民族関係一一日本人と在日韓国・朝鮮人との『結合一分離』志向—」, 奥田道大編『都市社会学叢書(7) 都市エスニシティの社会学——民族／文化／共生の意味を 問う—』ミネルヴァ書房, 177-204.

—，2008，「民族関係研究における生活構造論的アプローチの再検討」『都市社会学会年報』 26:73-85.

岩井孝夫, 2005, 「神戸南京町vs 横浜中華街」, 山下清海編『華人社会がわかる本一一国から世界 へ広がるネットワークの歴史，社会，文化』，明石書店，113-119.

梶田孝道・丹野清人・樋口直人，2005，『顔の見えない定住化一一日系ブラジル人と国家・市場・

移民ネットワーク』名古屋大学出版会.

二階堂裕子，2007,『民族関係と地域福祉の都市社会学』世界思想社.

野入直美，2004，「沖縄に打ける日系人・定住外国人の国境を越える移動とエスニック・ネットワ

ーク（上）—アメリカ人，台湾人，日系ペルー人，日系ブラジル人の意識調査から—」

『人間科学』14:271-289.

，2005，「沖縄における日系人・定住外国人の国境を越える移動とエスニック・ネットワ

ーク（中）—アメリカ人，台湾人，日系ペルー人，日系ブラジル人の意識調査から—」

『人間科学』15:91-113

， 2008，「生活史から見る沖縄・台湾の双方向的移動」，蘭信三編『日本帝国をめぐる人口

移動の国際社会学』不二出版,

沖縄県, 『沖縄統計年鑑』各年度版

，2009『おきなわ多文化共生推進指針』.

奥田道大・田嶋淳子編著, 1995, 『新版・池袋のアジア系外国人』明石書店.

小内透・酒井恵真，2001，『日系ブラジル人の定住化と地域社会』御茶の水書房.

高智富美，2008，「マルチエスニック・コミュニティにおける民族関係とエスニシティ一一大阪府

八尾市を事例として——」都市社会学会年報』26:187-203.

総務省, 2006, 『多文化共生推進プログラム』

鈴木規之・玉城里子，1996,「沖縄のフィリピン人——定住者としてまた外国人労働者として— (1)」琉大法学』57:39-66

—, 1997,「沖縄のフィリピン人——定住者としてまた外国人労㗢者として——(2)」琉大法 学』58:1-32

鈴木広，1986，「過剩都市化のメカニズム——那覇都市圏の事例—」」都市化の研究』恒星社厚生閣， 379-419.

玉野和志, 1992,「都市の新しいライフスタイル——社会層の分化と生活様式」森岡清志・松本康

編『都市社会学のフロンティア 2 生活・関係・文化』日本評論社, 161-188.

谷富夫編，2002,『民族関係における結合と分離』ミネルヴァ書房.

都築くるみ，1995,「地方産業都市とエスニシティ——愛知県豊田市 H団地に拈りる日系ブラジ ル人と地域住民」，松本康編『21 世紀の都市社会学 1 増殖するネットワーク』勁草書房, 235-281.

山脇啓造，2005，「2005年は多文化共生元年？」『自治体国際化フォーラム』187:34-37. 